\title{
Gender Wage Gap and Education: Case in Indonesia's Labor Market
}

\author{
Rr. Retno Sugiharti ${ }^{1}$ Akhmad Syakir Kurnia ${ }^{2}$ \\ ${ }^{12}$ Faculty of Economics and Business, Universitas Diponegoro
}

\begin{abstract}
The perspective gender wage gap weakens the labor market and deteriorates women's life quality. Women not only receive lower salaries than men, but also have lower employment rate in many countries due to discrimination. The aims of this study was to analyze gender wage gap by using the 2008-2016 panel data from 34 province in Indonesia. This study used derivatives canonical model in CES production function form to identify gender wage gap and elasticity substitution to observe the ability of female worker substitution of male labor in two group level education. The result of the regression panel consistently indicate that the gender wage gap exists in Indonesia.
\end{abstract}

Keywords: gender wage gap; education; elasticity substitution

\section{Introduction}

Considered as a second class society, the role of women in economic development is often in doubtfully as they are considered as inferior, unworthy and unable to work. The discriminatory perspective consider women doubtfully enable to fulfill even basic needs such as health, education, and economic prosperity [1].

The impact of gender discrimination perspectives is human resource accumulation for women labor was about to idle. Slowly and systematically, it was excluded women from access to resources, public services, or productive activities. Gender discrimination reduces the capacity of an economy to grow and reduces capacity to improve living standards.

In the labor market, the inability of women to fulfill the basic needs laid to degraded quality of human resources. This indirectly resulted in the wage earned by woman is lower than that of man, well known as gender wage gap. The gender wage gap, gender pay gap, or gender income inequality, is the differences in wages between women and men at the same level of productivity [2]. This idea was supported by Stojanka Dakić whose stated that gender wage gap is usually a result of breaking the principle of equal pay for work of equal value because the same work operated by different genders should have the same level of responsibility, expertise, experience and readiness in the intellectual and physical sense [3]. The low wages received by the female workforce causes the competence of female workers to be seen as lower than men. If this continues, the role of women in economic development becomes meaningless. The conclusion is that the gender wage gap has attributed to the lack of economic development.
In Indonesia, although the Gender Development Index has increased annually and exceeded the Human Development Index, the gender wage gap occurs as proven by the study of Feridhanusetyawan \& Perdana [4]; Taniguchi \& Tuwo [5]. The fact stated that although a decline occurs in gender gap in almost all gender development aspect, the highest gap occurs on the labor market ${ }^{1}$. The proportion of labor wages and in Indonesia can be seen in Figure 1 and 2.

Figure 1. Male and Female Wages

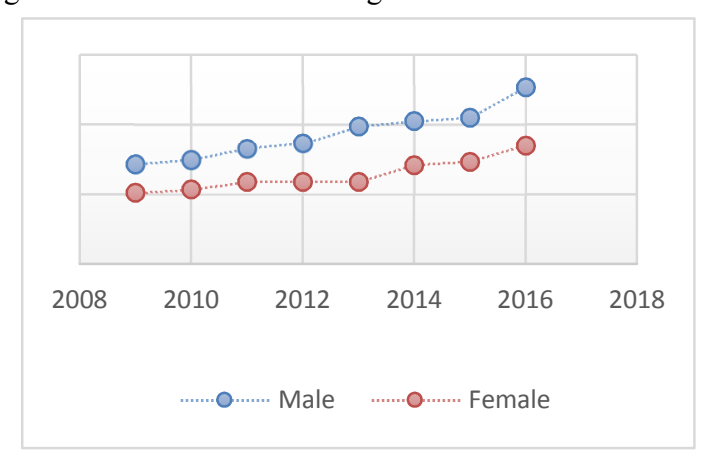

Figure 1.

\footnotetext{
* Corresponding author: sugiharti.retno@gmail.com
} 
Figure 2. Gender Deveopment Index and Human Capital Index

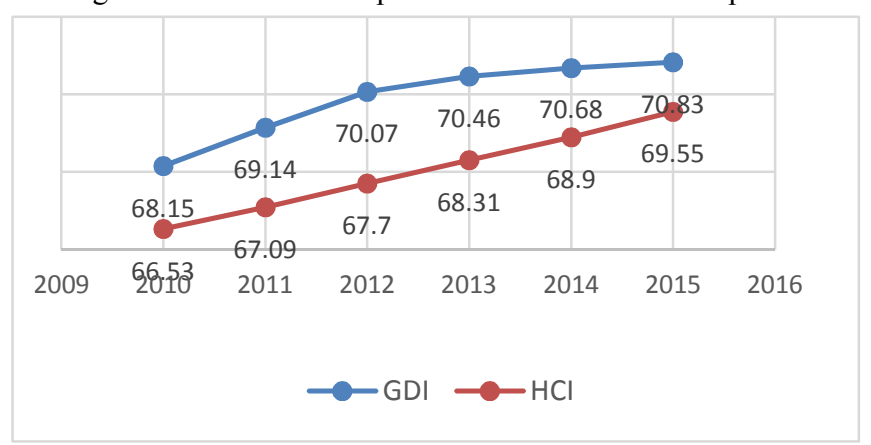

As one approach to tackling the gap, education is believed as the main determinant of raising human capital quality. The quality of labor education will be directly proportional to the job opportunity and wages received. From education's investment, individual will earn education's return. Return to education actually reflects the underlying ability that education signals - in other words education is a signal of inherent productivity of the individual rather than a means to enhance the productivity [6]. However, in the same level of education attainment, different labor can earn different level of return. Although in same education level, gender wage gap is exist, as women tend to receive lower wage than man [5]. It was indicated by the achievement of the level of education of women and men as measured by the average length of school shows an uptrend although not too significant [7].

Many previous studies have discussed related to gender wage gap. Using household survey data, research from Of [8], Dolado \& Lloren [9], Autor \& Dorn [10], and Fiaschi \& Gabbriellini [11] tried to analyze the gender wage gap problem. However, looking at the household scope only is not enough to see the gap of the wage gender at the labor market. There are needs to have a good comparison from the household to the macroeconomic framework particularly to analyze the role of education in overcoming the gender wage gap.

By related gender wage gaps to labor demand and labor supply gaps in two groups of labor (skilled and unskilled labor), the goals of this study was to calculated gender skiiled and unskiiled labor elasticity substitution. In addition to showing the effect of changes in the amount of labor on the wage level, indicating the substitution ability of male and female labor production factors, the substitution elasticity coefficient indicates the labor gap. the higher the value of substitution elasticity then the gap in the amount of labor will be lower, vice versa [12]

\section{Methodology}

The foundation of this research is the theory of demand and supply Labor. In wage and labor nexus, labor demand is the relationship between wages and the total amount of labor. This research refer to Acemoglu \& David Autor [13] whose build canonical model which divided two distinct skill group; high skill labor and low skill labor. Typically, canonical model identify high skill worker with college graduates and high school workers to identify low skill. This method to performing two distinct and imperfectly substitutable occupations or producing two imperfectly substitutable goods. In addition, the substitution between the two groups of workers is captured using a Constant Elasticity of Substitution (CES) aggregate production function. With $Q$ is aggregate output which produced by combination of skilled (S) and unskilled (U) labor in $j$ cross object, the CES production function written as follows:

$$
Q_{j}=\left[\alpha_{j} S_{j}^{\frac{\phi-1}{\phi}}+\left(1-\alpha_{j}\right) U_{j}^{\frac{\phi-1}{\phi}}\right]^{\frac{\phi}{\phi-1}}
$$

\section{$(\mathrm{Eq}$}

in Which is $\phi$ is elasticity of substitution between skilled $(S)$ and unskilled $(U)$ labor. Assuming that factor markets are competitive, the unskilled and skilled unit wages is simply given by the value of marginal product of low skill labor, which is obtained by differentiating (Eq. 1) as $\Delta w_{S}=\frac{\Delta Q}{\Delta S}$ for skilled labor and similarly $\Delta w_{U}=\frac{\Delta Q}{\Delta U}$ for unskilled labor. To quantify the gender and softskill of differences labor demand, relation between gender wage gaps to (measurable) gaps in labor demand and labor supply was built. Follows differenting step from Olivetti $\&$ Petrongolo ${ }^{10}$ cross-object differences in relative labor demand written as:

$$
\Delta w_{i}=\tilde{\beta}_{i}-\frac{1}{\sigma} \Delta h_{i}
$$

The wage gap for skill group $i(i=S, U) i$ is denoted by $\Delta w_{i}=\ln \left(\frac{W_{M i}}{W_{F i}}\right)$, which is $W_{M i}$ and $W_{F i}$ are gender specific wages. The gap in labor supply is denoted by $\Delta h_{i}=\ln \left(\frac{M_{i}}{F_{i}}\right)$, with $M_{i}=\Sigma_{j} M_{i j}$ and $F_{i}=\Sigma_{j} F_{i j}, \sigma$ is elasticity substitution and the gap in labor demand is denoted by $\tilde{\beta}_{i}{ }^{13}$. Under perfect competition in the labor market, all inputs are paid their marginal productivity and wages are equalized across sectors.

The research model was decomposition factor from the Eq. 4, written in econometric function, we estimates three function written as:

$$
\begin{aligned}
& w_{U i t}=\tilde{\beta}_{U i t}-\frac{1}{\sigma} h_{U i t}+e_{i t} \\
& w_{\text {Sit }}=\tilde{\beta}_{\text {Sit }}-\frac{1}{\sigma} h_{\text {Sit }}+e_{i t} \\
& w_{\text {USit }}=\tilde{\beta}_{\text {USit }}-\frac{1}{\sigma} h_{U S i t}+e_{i t}
\end{aligned}
$$

(Eq. 7)

Which is:

$W_{M i} \quad$ : labor male average wage for skill group $i$, unskilled (U) and skilled (S)

$W_{F i} \quad$ : labor female average wage for skill group $i$, unskilled (U) and skilled (S)

$M_{i} \quad$ : total male labor for skill group $i$, unskilled (U) and skilled (S)

$F_{i} \quad:$ total female labor for skill group $i$, unskilled (U) and skilled (S) 
$w u_{i t}:$ the unskilled labor wage gap, calculated from ratio of $W_{M U}$ and $W_{F U}$

$W S_{i t} \quad$ : the skilled labor wage gap, calculated from ratio of $W_{M S}$ and $W_{F S}$

$h_{U i t}:$ the unskilled total labor gap, calculated from ratio of $M_{M U}$ and $M_{F U}$

$h_{\text {Sit }} \quad:$ the skilled labor wage gap, calculated from ratio of $M_{M S}$ and $M_{F S}$

This study used a dataset of 33 provinces (actually in has 34 provinces, but Kalimantan Utara was removed from sample because the incompletely of data) in Indonesia during 2008 until 2016, retrieved from Badan Pusat Statistik (BPS). Fixed effect panel regression method was used to capture heterogeneity in Indonesian province.

\section{Discussion}

Estimation started with Hausman test to make sure that fixed effect is the best effect to estimate. From Hausman test result (Table 1) it surely that the best model for this research is fixed effect panel regression model. In order to get unbiased model, we used Robust Standard Error to conquer classical assumptions problems. The result shows in Table 1 below:
Eq. 9 is an equation for skilled labor model. From table 1 we conclude that the gender gap in the number of skilled labor $\left(h_{s}\right)$ has negative and significant effect at the 5 percent significance level to gender wage gap in the skilled labor $\left(w_{s}\right)$.

Elasticity substitution for unskilled labor (3.8751) lower than Elasticity substitution for skilled labor (7.1633). It is conclude that the ability of substitutions in the skilled labor group is higher than the ability of substitution of unskilled labor groups. Unskilled labor generally work in the informal sector, unskilled laborers or blue collar, so that in this group will be difficult to be replaced by women.

Estimation result for all labor written as: gapWs $_{i t}=0.47305-0.13960 h u_{i t}+e_{i t}$ (Eq. 10)

Eq. 10 is an equation for aggregate labor force model. From table 1 we conclude that the gender gap in the total labor force ( $g a p L)$ has negative and significant effect at the 5 percent significance level to gender wage gap in the skilled labor $\left(w_{s}\right)$.

Table 1. Fixes effect panel model in period 2008-2016

\begin{tabular}{|c|c|c|c|c|c|c|c|c|}
\hline Variables & Coeff & $\begin{array}{l}\text { Robust } \\
\text { S.E }\end{array}$ & $\mathrm{t}$ & \multicolumn{2}{|c|}{$\mathrm{P}>|\mathrm{t}|$} & $\mathrm{F}$ & $\mathrm{R}^{2}$ & \\
\hline$w u=f(h u)$ & hu & 0.25806 & 0.124 & 2.09 & 0.038 & $* *$ & $2.96^{*}$ & 0.220 \\
\hline $\begin{array}{c}\text { Hausman } \\
\chi 2: 6.17, \mathrm{p}: 0.0130\end{array}$ & cons & 0.31861 & 0.159 & 2.00 & 0.046 & $* *$ & & \\
\hline$w s=f(h s)$ & hs & $0.13960^{-}$ & 0.034 & -4.15 & 0.000 & $*$ & $7.50^{*}$ & 0.386 \\
\hline $\begin{array}{c}\text { Hausman } \\
\chi 2: 12.19, \mathrm{p}: 0.0005\end{array}$ & cons & 0.29799 & 0.020 & 15.14 & 0.000 & $*$ & & \\
\hline$g a p W=f(g a p L)$ & gapL & $0.15821^{-}$ & 0.074 & -2.16 & 0.033 & $* *$ & $5.34^{*}$ & 0.313 \\
\hline $\begin{array}{l}\begin{array}{l}\text { Hausman } \\
\chi 2: 4.93, \mathrm{p}:\end{array} \\
0.0264\end{array}$ & cons & 0.47305 & 0.059 & 8.07 & 0.000 & $*$ & & \\
\hline
\end{tabular}

Numbers in the table are the coefficients of each variables (Source: Stata14 output, 2017) ***: 10\% significance level, **: $5 \%$ significance level, *: $1 \%$ significance level

\section{Conclusion}

Estimation result for unskilled labor written as:

$$
w u_{i t}=0.31861+0.25806 h u_{i t}+e_{i t}
$$

Eq. 8 is an equation for unskilled labor model. From table 1 we conclude that the gender gap in the number of unskilled labor $\left(h_{u}\right)$ has positive and significant effect at the 5 percent significance level to gender wage gap in the unskilled labor $\left(w_{u}\right)$. This consistent with result from Olivetti \& Petrongolo [12] that positive correlation is exist between wage and total labor force. This positive result conclude that the higher the number of unskilled male labor the higher the wage gap, meaning that unskilled male workers are increasingly dominating in the informal sectors.

Estimation result for skilled labor written as:

$$
w s_{i t}=0.29799-0.13960 h u_{i t}+e_{i t}
$$

This paper highlighted the importance contribution of education to gender wage gap. Divided to skilled and unskilled labor, the result has revealed positive and significant nexus between gap of total unskilled labor and wage gap in unskilled labor, and negative significant nexus between gap of total skilled labor and wage gap in skilled labor. The ability of substitutions in the skilled labor group is higher than the ability of substitution of unskilled labor groups. So that, skilled women easily replace skilled man labor rather than unskilled. so that, female skilled labor more easily replace male skilled labor rather than female unskilled labor replace unskilled male labor. Jobs for unskilled male labor not be easy to replace by women, because the jobs usually low level jobs. 


\section{References}

1. Badan Pusat Statistik, Pembangunan Manusia Berbasis Gender 2016, (2016).

2. A. G. Navarro, Gender Wage Gap and Education: Case in Dominican Republic (2015).

3. M. S. Stojanka Dakić, Application Of The Mincer Earning Function In Analyzing Gender Pay Gap In Serbia (Economics and Organization Vol., 14 (2, 2017), 155-162 (2017).

4. T. Feridhanusetyawan, A. A. Perdana, The MaleFemale Wage Differentials in Indonesia (2004).

5. K. Taniguchi, A. Tuwo, New Evidence on the Gender Wage Gap in Indonesia, 404.1 (2014).

6. A. M. Dockery, P. W. Miller, Over-education, Under-education and Credentialism in the Australian Labour Market (NCVER, Adelaide 2012).

7. BPS, Badan Pusat Statistik (2015).

8. O. Of, The Wage Gap between Men and Women in Botswana 's Formal Labour Market Happy Kufigwa Siphambe and University of Botswana,
(Comparative and General Pharmacology, 127-142 2001).

9. J. J. Dolado, V. Llorens, Gender Wage Gaps by Education in Spain: Glass Floors versus Glass Ceilings (Labour Economics 21(4203), 2-55, 2004).

10. D. H. Autor, D. Dorn, The growth of low-skill service jobs and the polarization of the US Labor Market (American Economic Review, 103(5), 1553-1597, 2013).

11. D. Fiaschi, C. Gabbriellini, Wage Functions and Rates of Return to Education in Italy, 1-37 (2013).

12. C. Olivetti, B. Petrongolo, Gender gaps across countries and skills: Demand, supply and the industry structure (Review of Economic Dynamics 17(4), 842-859 (2014).

13. D. Acemoglu, David Autor, Skills, Tasks And Technologies: Implications For Employment and Earnings (2010).

14. Badan Pusat Statistik, Indeks Pembangunan Gender 2014, (2015).

* Corresponding author: sugiharti.retno@gmail.com 